9. Федотова Ю. $\boldsymbol{K}$. К вопросу о содержании основных пигментов фотосинтетического аппарата у Geranium sanguineum флоры центрального Предкавказья. Вестник МГОУ. Серия Естественные науки. 2009. № 1. С. 81-84.

10. Федулов Ю. П., Подушин Ю. В. Содержание и соотношение хлорофиллов в листьях озимой пшеницы в зависимости от агротехнических приемов ее выращивания. $H a$ учнылй журнал КубГАУ. 2009. № 51. С. 1-13.

11. Шадрин В. А., Куприянов $\boldsymbol{A}$. Н. Динамика содержания хлорофилла и степень оводненности листьев газонных трав. Вестник Алтайского гос. ун-та. 1998. № 1 (5). С. 137.

12. Шкура О. В. Кластеризація перспективних видів та сортів газонних трав за основними ростовими параметрами. Корми $і$ кормовиробнищтво. 2012. Вип. 74. С. 258-262.

13. Шлык A. A. Определение хлорофиллов и каратиноидов в экстрактах зеленых листьев. Биохимические методы в физиологии растений. Москва: Наука, 1971. С. 154-170.

14. Kwiatkowska D. Structural integration at the shoot apical meristem: models, measurements, and experiments. American journal of botany. 2004. Vol. 91. P. 1277-1293.

15. Eckardt N. A CLASSY RNA silencing signaling mutant in arabidopsis. Plant Cell. 2007. Vol. 19. P. 1439.

16. Matthew $\boldsymbol{C}$. Translocation from flowering to daughter tillers in perennial ryegrass (Lolium perenne L.). Austral. J. Agr. Res. Vol. 53, № 1. 2002. P. 21-28.

17. Tikhankov I. Heteroblasty of the Lolium perenne L. Visnyk of Lviv Univ. Biology series. 2009. Is. 49. P. 53-62.

Надійила до редколегії 12.04.2017 p.

УДК $581.5+581.8$

I. О. Тіханков, В. М. Зверковський

Дніпровський національний університет імені Олеся Гончара

\title{
ПРИСТОСОВАНІСТЬ ОКРЕМИХ СОРТIВ LOLIUM PERENNE L. ДО РІЗНОГО РІВНЯ ОСВІТЛЕННЯ В УМОВАХ ПРИРОДНОГО СЕРЕДОВИЩА
}

Вивчено пристосованість різних сортів Lolium perenne L. до інтенсивності світлового опромінювання і температури як супутнього фактора. Протягом вегетаційного періоду проаналізовано динаміку сухої маси надземної частини рослин, інтенсивність відростання трави після скошування, кількості пагонів, а також ступінь задерніння грунту і товщина дернового шару.

Ключові слова: пажитниця, освітлення, температура, суха маса, дерен.

\section{И. А. Тиханков, В. Н. Зверковский}

Днепровский национальный университет имени Олеся Гончара

\section{ПРИСПОСОБЛЕННОСТЬ НЕКОТОРЫХ СОРТОВ LOLIUM РЕRЕNNE L. К ОСВЕЩЕНИЮ РАЗНОЙ ИНТЕНСИВНОСТИ В ПРИРОДНЫХ УСЛОВИЯХ}

Изучена приспособленность разных сортов Lolium perenne L. к интенсивности освещения и температуры как сопутствующего фактора. На протяжении вегетационного периода проанализирована динамика сухой массы надземной части растений, интенсивность отрастания травы после скашивания, количество стеблей, а также степень задерненности грунта и толщина дерна.

Ключевые слова: райграс, освещение, температура, сухая масса, дернина.

(C) I. О. Тіханков, В. М. Зверковський, 2017 


\author{
I. O. Tikhankov, V. M. Zverkovsky \\ Dnipro National University of Oles Gonchar
}

\title{
ADAPTATION OF SOME VERIETIES OF LOLIUM PERENNE L. TO THE LGHIT IRRADIATION OF VERIOUS INTENSITY IN NATURAL ENVIRONMENT
}

It has been studied the adaptation of some varieties of Lolium perenne L. to light of verious intensity and temperature as a concomitant factor. The experiment has been made in field condition and continued two years. Such ecological parameters as temperature, precipitation amount, air humidity and cloudiness were monitored during this period. The shadow was made using masking nets. The dynamics of dry mass of the above-ground part of the plant, grass grow intencity after mowing, number of tillers and turf development has been analysed during vegetation period. It has been appreciated that shade-tolerant variety gives more dry mass then sun plants in any case. The differences between varieties in this parameter enlarged when the sun irradiation was increasing and became more less in the parameter of grass alongation. Generally shade-tolerant variety manifested more intensive gross then the sun one. The tillering depended from light intensity much more in the case of shade-tolerant variety. Root formation was more intensive in the sun then in the shadow and sun variety created tighter layer of the turf then the shade-tolerant one.

Keywords: ryegrass, lghit, temperature, dry mass, turf.

Пажитниця багаторічна Lolium perenne L. характеризується низкою властивостей, які роблять цю рослину незамінною при створенні газонів $[5,7,8]$ і вельми перспективною для розширення кормової бази у тваринництві $[2,8]$. Однак вимоги до газонних сортів відрізняються від тих, що пред’являються до кормових трав. Більш того, оскільки газони виконують різні функції, то під них спеціально виведено різні сорти пажитниці [2; 15]. Так, спортивні газони повинні мати щільну і пружну дернину, достатню стійкість до витоптування. Компоненти газонів для ландшафтного дизайну мають бути пристосовані до різного типу грунтів і різного рівня освітлення. Вимоги до властивостей дерну $є$, у цьому випадку, менш жорсткими. Трави для газонів також мають характеризуватися незначними темпами росту, щоби уникнути частих скошувань, оскільки при цьому підвищується ризик захворювань на Puccinia dispersa i Corticum fuciforme [9; 16] і погіршуються властивості дернини [3; 9]. На противагу цьому трави на пасовищах мають характеризуватися високими темпами росту, стійкістю до полягання, а потужність дернини при цьому особливого значення не має [19].

3 огляду на такі протилежні вимоги проводиться селекція пажитниці з метою виведення сортів, найкраще пристосованих до конкретних умов навколишнього середовища, одним з ключових факторів якого є рівень освітлення, що нерозривно пов'язаний з температурним режимом [11]. Рослини, опинившись в умовах, відмінних від оптимальних, намагатимуться в межах своєї пластичності протидіяти зовнішньому несприятливому впливу. Таким чинником може бути надмірний рівень освітлення або значна нестача сонячної радіації [12; 20]. В обох випадках рослини опиняються у стресових умовах. Але у першому варіанті ще діє чинник підвищеної температури. Все це необхідно враховувати при утриманні газонів і пасовищ, оскільки неправильний менеджмент може призвести до цілого ряду проблем екологічного і економічного характеру. Тобто необхідно в першу чергу знати реакцію окремих сортів на зміну інтенсивності дії екологічних факторів.

Метою роботи стало дослідження двох сортів пажитниці від фірми Trifolium в нормальних умовах і умовах стресу, спричиненого зміною інтенсивності освітлення і температури, як супроводжуючого фактора.

Об'єкти та методи дослідження. Для проведення дослідів було обрано сорти пажитниці Rapid i Esquire від фірми Trifolim, які призначені для вирощуван- 
ня в умовах сильного затінення та на відкритих ділянках відповідно. Дослідні ді-

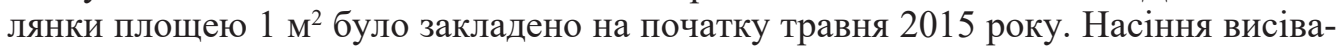
лося у відкритий грунт з розрахунку 20 г/м² , що давало приблизно 6500 рослин на $1 \mathrm{M}^{2}$. Матеріал для аналізів відбирався наступного року раз на місяць 3 травня по вересень включно 3 площі 20×20 см [1; 17]. Літо і початок осені 2015 і 2016 років характеризувались однаковими погодними умовами. Середньомісячна температура в районі закладки дослідів складала в літні місяці $23-24^{\circ} \mathrm{C}$, хмарність коливалася в межах 10-20\%, вологість повітря від 27 до 35 \%. Влітку 2015 р. випало 178,3 мм опадів, а у 2016 - 173,0 мм. Гідротермічний коефіціснт (ГТК) набував максимальних значень на початку літа $(1,85-1,95)$ і поступово зменшувався до 0,25-0,35 наприкінці літа. Вересень був сухим і теплим з ГТК 0,14 у 2015 p. i 0,20 у 2016 р. Однак травень 2016 р. характеризувався щоденними дощами, і ГТК для нього був 3,72 проти 1,99 у 2015 р. Починаючи з кінця червня, проводився раз у 2 дні додатковий полив з розрахунку 10 л води на 1 м². Зима була м'якою 3 періодичними опадами, середньомісячна температура опустилася нижче нуля тільки у січні 2016 і склала $-6^{\circ} \mathrm{C}$. Затінення створювалося за допомогою маскувальної сітки. На таких ділянках середній рівень освітлення протягом дня склав 5000 лк, на відкритих ділянках - 12000 лк.

Всі аналізи проводились у трикратній повторності. Статистична обробка включала визначення середнього квадратичного відхилення і коефіцієнтів Стьюдента на $5 \%$ рівні значимості [4].

Результати дослідження та їх обговорення. В лабораторних дослідах було встановлено, що за однакових умов вирощування тіньовитривалий сорт Rapid має більшу швидкість росту, ніж світлолюбний Esquire [10], і рослини досягали більшої висоти. Те саме спостерігалось і в польових дослідженнях після скошування на затінених ділянках (табл. 1). Однак при повному освітленні темпи росту у Esquire виявилися дещо вищими, ніж у Rapid, або однаковими, що залежало від місяця, коли проводилося скошування. Ці сорти проявили прямо протилежну реакцію на зміну інтенсивності освітлення. У Esquire темп відростання за повного освітлення дещо зріс, а у Rapid, навпаки, знизився, i ці зміни були більш суттєвими.

Таблиия 1

Відростання травостою Lolium perenne L. (см) за 10 діб після скошування

\begin{tabular}{|c|c|c|c|c|c|c|}
\hline \multirow{2}{*}{ Сорт } & \multirow{2}{*}{$\begin{array}{c}\text { Освітлення } \\
\text { (лк) }\end{array}$} & \multicolumn{5}{|c|}{ Місяць } \\
\cline { 3 - 7 } & & травень & червень & липень & серпень & вересень \\
\hline \multirow{2}{*}{ Esquire } & 12000 & $10,5 \pm 0,3$ & $7,0 \pm 0,4$ & $6,0 \pm 0,3$ & $6,0 \pm 0,2$ & $10,0 \pm 0,5$ \\
\cline { 2 - 7 } & 5000 & $9,5 \pm 0,2$ & $6,5 \pm 0,2$ & $5,0 \pm 0,3$ & $6,0 \pm 0,4$ & $9,0 \pm 0,2$ \\
\hline \multirow{2}{*}{ Rapid } & 12000 & $10,0 \pm 0,4$ & $6,0 \pm 0,3$ & $6,5 \pm 0,4$ & $6,0 \pm 0,2$ & $8,0 \pm 0,3$ \\
\cline { 2 - 7 } & 5000 & $12,0 \pm 0,5$ & $9,0 \pm 0,6$ & $8,0 \pm 0,5$ & $8,0 \pm 0,5$ & $10,0 \pm 0,4$ \\
\hline
\end{tabular}

При цьому у травні суха маса трави сорту Rapid збільшилася за умов інтенсивнішого освітлення (табл. 2) в 1,67 раза, тоді як для Esquire це зростання було меншим у 1,54 разів. У перші два місяця літа, коли настала депресія росту, різниця між сортами по реакції на інтенсифікацію освітлення була відсутня, збільшення сухої маси трави було в межах 1,44-1,48 раза. Однак у серпні приріст сухої маси Esquire знизився до 1,30 раза, тоді як для Rapid залишився таким, як у попередньому місяці - 1,44. Осінній вихід 3 депресії супроводжувався більш інтенсивним нарощуванням сухої маси за інтенсивнішого освітлення, хоча і не досяг того рівня, що був навесні. При цьому сорт Rapid знову випереджав сорт Esquire. Але у будь-який місяць вегетативного періоду в обох варіантах освітлення суха маса трави Rapid була більше, ніж у Esquire. 
Суха маса трави пажитниці $\left(г / \mathbf{M}^{2}\right)$

\begin{tabular}{|c|c|c|c|c|c|c|}
\hline \multirow{2}{*}{ Сорт } & \multirow{2}{*}{ Освітлення (лк) } & \multicolumn{5}{|c|}{ Місяць } \\
\cline { 3 - 7 } & & травень & червень & липень & серпень & вересень \\
\hline \multirow{2}{*}{ Esquire } & 12000 & $530 \pm 15$ & $450 \pm 17$ & $455 \pm 24$ & $410 \pm 19$ & $490 \pm 26$ \\
\cline { 2 - 7 } & 5000 & $345 \pm 21$ & $310 \pm 11$ & $315 \pm 26$ & $315 \pm 24$ & $330 \pm 13$ \\
\hline \multirow{2}{*}{ Rapid } & 12000 & $720 \pm 30$ & $600 \pm 24$ & $570 \pm 19$ & $560 \pm 28$ & $670 \pm 30$ \\
\cline { 2 - 7 } & 5000 & $430 \pm 21$ & $405 \pm 27$ & $395 \pm 31$ & $390 \pm 35$ & $415 \pm 27$ \\
\hline
\end{tabular}

Приріст біомаси залежить не лише від росту листків у довжини і ширину, але також й від інтенсивності кущення, що визначається кількістю пагонів на квадратний метр. При цьому виявилося, що у світлолюбного Esquire кількість пагонів була більшою, ніж у Rapid, і навесні їх утворення перебігало інтенсивніше, ніж у осінній період (рис. 1). У тіньовитривалого Rapid кількість пагонів у весняний і осінній періоди була приблизно однаковою в обох варіантах освітлення. Обидва сорти демонстрували зниження інтенсивності утворення пагонів за умов затінення, але в Esquire воно було більш суттєвим.
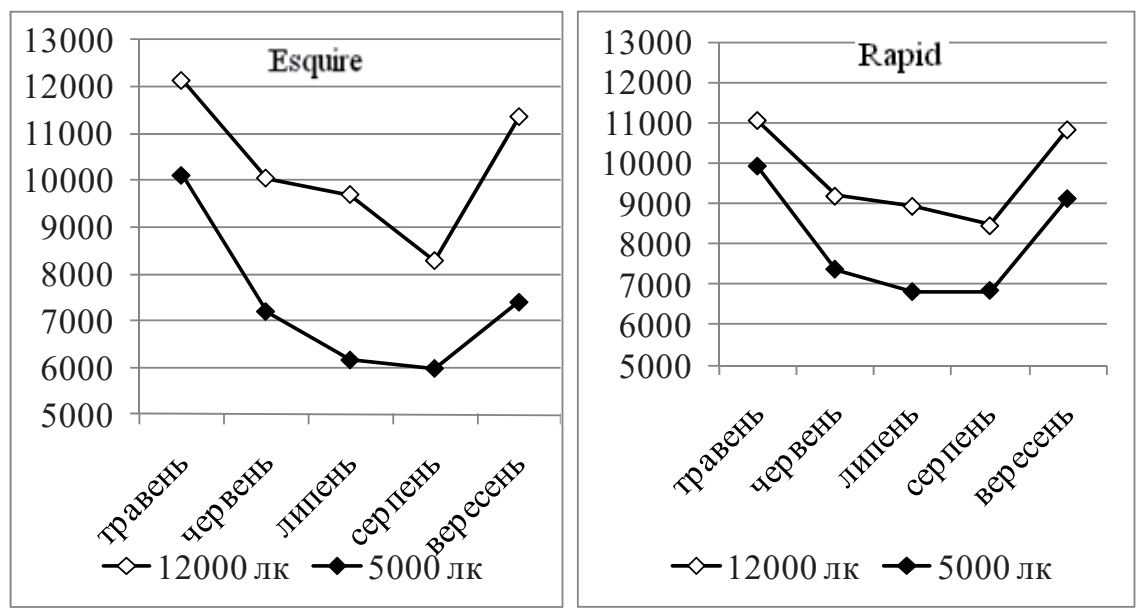

Рис. 1. Кількість пагонів на 1 м² $^{2}$ сортів Esquire i Rapid протягом вегетаційного періоду

Розвиток надземної частини залежить від розвитку кореневої системи, яка меншою мірою піддається впливу мінливих зовнішніх факторів. Виявилося, що суха маса коренів була в середньому у 4 рази меншою за суху масу надземної частини рослин. При цьому динаміка зміни цих двох параметрів протягом травня вересня була подібною, з тією різницею, що коливання маси коренів були не такими значними. Основна маса коренів у сорту Esquire за освітлення ділянки у 12000 лк проникає на глибину до 6,0 см, а при 5000 лк - на глибину 7,5 см. Для сорту Rapid ці показники є більшими, 7,5 і 8,0 см відповідно. Однак при цьому густина коренів на глибині 5,0 см є більшою за умов інтенсивнішого освітлення для обох сортів, зокрема і сорту Esquire, який призначений для висадки на відкритих ділянках. Про це свідчать значення такого показника, як об'ємна маса дернини (табл. 3).

Cорт Rapid є краще пристосованим до умов затінених ділянок, де переважає розсіяне світло. Натомість сорт Еsquire призначений для висіву на відкритих ділянках. Тому середній рівень освітлення в 12000 лк діяв стосовно першого сорту як стресовий фактор. До цього додалося підвищення температури тканин, спричинене прямим сонячним світлом. Як відомо, світло відіграє значну регуляторну 
роль у морфогенезі рослин, що проявляється у зменшенні їх висоти, потовщенні листків тощо. Тобто обмежується ріст у довжину. Більш висока температура навколишнього середовища спричиняє інтенсифікацію транспірації і послаблення тургорного тиску, який забезпечує елонгацію клітин. Наслідком цього є зменшення розмірів клітин, а значить, і зниження інтенсивності росту. Саме 3 цих причин відбулося зниження інтенсивності відростання у Rapid на 20 \% при високому рівні освітлення. Це зниження могло бути ще сильнішим за умов послаблення поливу. Повна відсутність додаткового поливу призвела би до загибелі рослин, оскільки у степовій зоні гідротермічний коефіцієнт у червні - вересні значно нижче того критичного значення 0,84, коли газонні трави починають вигоряти [7]. Для сорту Esquire, навпаки, стресом буде зниження рівня освітлення. Однак невелика різниця у темпах відростання цього сорту на обох ділянках свідчить про те, що освітлення в 5000 лк навряд чи можна назвати стресовим фактором, швидше за все, такі умови є просто менш сприятливими для цього сорту, ніж освітлення в 12000 лк, яке забезпечує високий рівень фотосинтезу [18]. Крім цього, при аналізі відмінностей між сортами слід враховувати той факт, що тіньовитривалі рослини мають більшу пластичність порівняно зі світлолюбними [2].

Таблиия 3

Об'смна маса дернини $\left(г / \mathrm{cm}^{3}\right)$

\begin{tabular}{|c|c|c|c|c|}
\hline \multirow{2}{*}{ Сорт } & \multirow{2}{*}{ Освітлення (лк) } & \multicolumn{3}{|c|}{ Місяць } \\
\cline { 3 - 5 } & & травень & липень & вересень \\
\hline \multirow{2}{*}{ Esquire } & 12000 & $1,13 \pm 0,02$ & $1,02 \pm 0,03$ & $1,11 \pm 0,04$ \\
\cline { 2 - 5 } & 5000 & $1,03 \pm 0,03$ & $0,95 \pm 0,01$ & $1,00 \pm 0,02$ \\
\hline \multirow{2}{*}{ Rapid } & 12000 & $0,98 \pm 0,01$ & $0,89 \pm 0,04$ & $0,97 \pm 0,03$ \\
\cline { 2 - 5 } & 5000 & $0,85 \pm 0,03$ & $0,70 \pm 0,02$ & $0,88 \pm 0,01$ \\
\hline
\end{tabular}

Ріст рослин не обмежується збільшенням їх висоти. Іншими складовими росту трав $є$ зростання ширини листків, їх потовщення і кількість нових пагонів. Ці параметри не є сталими протягом вегетаційного періоду, а динамічно змінюються [14]. Інтегральним показником росту може бути суха маса трави. Динаміка ії зміни така сама, як і кожного з розглянутих параметрів, це зниження протягом літніх місяців і зростання на початку осені. Однак, на відміну від висоти трави, суха маса у сорту Rapid збільшилася при підвищенні освітлення до 12000 лк. Це можна пояснити інтенсивнішим ростом листків у товщину і ширину, що не є характерним для світлолюбного Esquire. У вересні збільшення маси обумовлено не лише ростом листків, а й кущенням, яке стимулюється зниженням температури і скороченням світлового дня. Такі тенденції притаманні й сорту Esquire. Відмінністю між сортами $є$ те, що тіньовитривалий Rapid демонструє більшу пластичність $\mathrm{i}$ дає більше сухої маси порівняно зі світлолюбним Esquire. Висока продуктивність Rapid вказує на можливість його використання не лише як газонної трави, але також як кормового сорту.

Навесні та восени приріст маси залежить також від інтенсивності кущення, коли формуються бічні пагони. Для пажитниці їх максимальна кількість доходить до трьох на рослину [14]. Цей показник є динамічним, оскільки тривалість життя таких пагонів коливається від кількох тижнів до кількох місяців [14]. Як правило, влітку настає період депресії, коли утворення нових пагонів зупиняється. Однак за умов достатньої вологості, коли гідротермічний коефіцієнт більше одиниці, скошування трави на стадії 3-х листків на висоту не нижче 3-4 см, внесення добрив цей процес може продовжуватись [6; 13]. При максимальному освітленні кущення було більш інтенсивним у світлолюбного Esquire, а при 5000 лк - у тіньовитривалого Rapid, оскільки утворення нових пагонів дуже сильно подавлялося саме у світлолюбного сорту. Утворення нових пагонів слід розглядати 3 двох то- 
чок зору. Перше - це може бути показник пристосованості рослин до конкретних

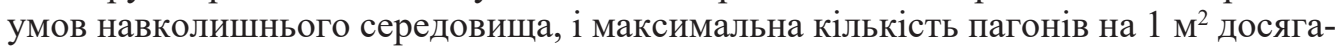
ється за оптимальних умов. Зменшення кількості пагонів може бути мірою відхилення цих умов від оптимальних. Друге - це реакція рослин на стрес, спричинена скошуванням чи поїданням трави тваринами. Рослини намагаються збільшити листову поверхню усіма можливими способами, зокрема через виникнення нових апікальних меристем у точках кущення. Для цього необхідно, щоби коренева система була достатньо добре розвинена.

Пажитниця відома тим, що не утворює міцної дернини, іiі зв'язність є доволі низькою - 0,15-0,22 кг/ $\mathrm{cm}^{2}$ [3]. Більшість їі підземної біомаси знаходиться на глибині до 9 см, що залежить від сорту і умов навколишнього середовища, зокрема рівня освітлення. Чим інтенсивніше освітлення, тим тонше шар дерну, але при цьому збільшується об'ємна маса дернини, зменшення інтенсивності освітлення до 5000 лк призвело до більш суттєвих змін у світлолюбного Esquire.

В цілому можна підсумувати, що для пажитниці більшим стресом є не збільшення інтенсивності освітлення і температури як супутнього фактора, а ії зниження. Тіньовитривалі сорти можна було би використовувати не лише для створення газонів, але і для покращення кормової бази, оскільки вони дають більше сухої маси і характеризуються інтенсивнішим ростом.

Висновки. На відкритих ділянках різниця між тіньовитривалим сортом і світлолюбним по темпах відростання травостою практично відсутня. Вона збільшується по мірі зниження інтенсивності освітлення, і тіньовитривалий сорт демонструє більш високі темпи росту у довжину.

Тіньовитривалий сорт завжди дає більше сухої маси, ніж світлолюбний. При підвищенні інтенсивності освітлення відмінності між сортами за цим показником посилюються.

Пагоноутворення у тіньовитривалого сорту меншою мірою залежить від інтенсивністі освітлення, ніж у світлолюбного.

Ступінь задерніння грунту збільшується за умов підвищення інтенсивності освітлення в обох сортів, але у світлолюбного сорту він завжди більший.

\section{Бібліографічні посилання}

1. Бессонова В. П., Иванценко О. Е. Изменение содержания хлорофилла в ассимиляционных органах газонных трав и их рост на фоне действия физиологически активных веществ и нитрофоски в условиях загрязнения среды. Питання біоіндикації та екологї̈. 2012. № 17-2. С. 33-45.

2. Іванців $\boldsymbol{P} . \boldsymbol{G}$. Вивчення вихідного матеріалу для селекції пажитниці багаторічної в умовах Передкарпаття. Передгірне та гірське землеробство і тваринниитвво. 2013. Вип. 55, Ч. 1. С. 36-42.

3. Лазарев Н. Н., Гусев М. А. Комплексная оценка сортов и видов газонных трав при выращивании рулонного газона в условиях Московской области. Известия ТСХА. 2014. Вып. 6. С. 69-80.

4. Лакин Г. Ф. Биометрия. Москва: Высшая школа, 1990. 352 с.

5. Лаптев А. А. Газоны. Киев: Наукова думка, 1983. 176 с.

6. Мельник М. I. Вплив пасовищного використання на зміну щільності різночаснодозріваючих злаково-бобових травосумішок. Передгірне та гірське землеробство і тваринництво. 2014. Вип. 56. С. 41-50.

7. Ревунова Л. Г., Рахметов Д. Б. Біолого-морфологічні особливості інтродукованих газонних трав в умовах Національного ботанічного саду ім. М.М. Гришка НАН України. Вісник Харківського наи. ун-ту. Серія: Біологія. 2014. Вип. 20, №. 1100. С. 61-68.

8. Сердюк М. А., Сердюк О. М., Шкура О. В. Нові сорти низових злакових трав для озеленення. Зб. наук. пращь ННЦ «Інститут землеробства УААН». 2008. Вип. 2. С. 110-120.

9. Соколова В. В., Лазарев Н. Н. Эксплуатационные показатели дернины газонных травостоев. Научные ведомости. Серия Естественные науки. 2014. Вып. 27, № 10. С. $63-$ 69. 
10. Tіханков I. O. Показники росту, як критерії оцінки гетеробластії дерноутворюючих трав. Науковий вісник Ужгородського університету. Серія Біологія. 2008. Вып. 24. C. $227-233$.

11. Федотова Ю. К. К вопросу о содержании основных пигментов фотосинтетического аппарата у Geranium sanguineum флоры центрального Предкавказья. Вестник МГОУ. Серия Естественные науки. 2009. № 1. С. 81-84.

12. Dias-Filho M. B. Growth and biomass allocation of the $\mathrm{C}_{4}$ grasses Brachiaria brizantha and B. humidicola under shade. Pesq. Agropec. Bras. 2000. Vol. 35. № 12. P. 2335-2341.

13. Hunt $\boldsymbol{W} . \boldsymbol{F}$. Fifty years of ryegrass research in New Zealand. Proceedings N.Z. grassland association. 1989. Vol. 50. P. 11-23.

14. Hunt W. F., Field T. R. Growth characteristics of perennial ryegrass. Proceedings N.Z. grassland association. 1979. Vol. 40. P. 104-113.

15. Registration of Repell II perennial ryegrass. R. H. Hurley, V. G. Lehman, D. C. Funk, C. R. Funk Crop. Science. 1994. Vol. 34. № 5. P. 1409-1410.

16. Index of species information. Spicies: Lolium perenne. URL: https://www.fs.fed. us/database/feis/plants/graminoid/lolper/all.html (last access: 10.09.17). Index of species information.

17. Kays S., Harper $\boldsymbol{J}$. L. The regulation of plant and tiller density in a grass sword J. Ecology. 1974. Vol. 62, № 1. P. 97-105.

18. Ort D. $R$. When there is too much light. Plant Physiology. 2001.Vol. 125. P. $29-32$.

19. Perennial ryegrass management - grazing management to maximise growth and nutritive value. URL: https://www.dairyaustralia.com.au/farm/feedbase-and-animal-nutrition/ pasture/perennial-ryegrass-management

20. Woledge $\boldsymbol{J}$. The effect of light intensity during growth on the subsequent rate of photosynthesis of leaves of tall fescue (Festuca arundinacea Schreb.). Ann. Bot. 1971. Vol. 35. № 2. P. 311-322.

Надійшла до редколегії 1.10.2017 p.

В. М. Зверковський, В. Д. Калько

Дніпровський національний університет імені Олеся Гончара

\section{КОНСТРУЮВАННЯ РЕКУЛЬТИВАЦЙНОГО ШАРУ НА ПОРУШЕНИХ ЗЕМЛЯХ ЗАХІДНОГО ДОНБАСУ}

Досліджено фізико-хімічні та агрохімічні показники шахтних порід і штучних грунтів ділянки рекультивації на порушених землях шахти «Тернівська». Встановлено властивості і показники субстратів рекультиваційного шару, що впливають на лісопридатність і формують специфічний тип лісорослинних умов на штучних грунтах ділянки рекультивації.

Ключові слова: рекультивація, шахтна порода, штучні грунти, фізико-хімічні властивості, ступінь лісопридатності.

\section{В. Н. Зверковский, В. Д. Калько \\ Днепровский национальный университет имени Олеся Гончара \\ КОНСТРУИРОВАНИЕ РЕКУЛЬТИВАЦИОННОГО СЛОЯ НА НАРУШЕНННЫХ ЗЕМЛЯХ ЗАПАДНОГО ДОНБАСА}

Исследованы физико-химические и агрохимические свойства шахтных пород и искусственных почво-грунтов участка рекультивации на нарушенных землях шахты «Терновской». Определены свойства и показатели субстратов рекультива-

(C) В. М. Зверковський, В. Д. Калько, 2017 